\title{
Population Estimation of Proboscis Monkeys in Mangroves at Kuching Wetland National Park, Sarawak
}

\author{
AHMAD FITRI AZIZ* \& CHARLIE JUSTIN MERGIE LAMAN \\ Faculty of Resource Science and Technology, Universiti Malaysia Sarawak, 94300 Kota Samarahan, \\ Sarawak, Malaysia \\ *Corresponding author: fitziz61@gmail.com \\ Received: 23 February 2018 \\ Accepted: 5 November 2018 \\ Published: 30 December 2018
}

\begin{abstract}
Boat survey on proboscis monkey (Nasalis larvatus) population in Kuching Wetland National Park (KWNP) was conducted to estimate the current population density and population size of this primate. The survey was conducted on September 2015 and January 2016 covering a cumulative distance of $128.91 \mathrm{~km}$ of mangrove riverbank. A cumulative total of 158 individuals comprising 19 groups, including one all-male group and three solitary males were recorded throughout the survey. The population density of proboscis monkeys in mangrove forest at KWNP was estimated at 1.63 individuals $/ \mathrm{km}^{2}$ or 0.20 groups $/ \mathrm{km}^{2}$. Based on the extrapolation of the estimated population density data, the population size of proboscis monkey in mangrove forest at KWNP was estimated to be 82 individuals. Last published report on the estimation of proboscis monkey population in Sarawak was more than 30 years ago. This study was conducted as a part of the efforts to assess the current population status of proboscis monkey in Sarawak.
\end{abstract}

Keywords: Estimation, population density, population size, proboscis monkey

Copyright: This is an open access article distributed under the terms of the CC-BY-NC-SA (Creative Commons Attribution-NonCommercial-ShareAlike 4.0 International License) which permits unrestricted use, distribution, and reproduction in any medium, for non-commercial purposes, provided the original work of the author(s) is properly cited.

\section{INTRODUCTION}

Proboscis monkey (Nasalis larvatus) is a large sexually dimorphic Colobine primate that is endemic to Borneo. It occurs in Brunei, Indonesia (Kalimantan) and East Malaysia (Sabah and Sarawak). An adult male proboscis monkey can be easily identified by its large and pendulous nose. However, an adult female proboscis monkey possesses a smaller and pointed nose (Phillipps \& Phillipps, 2016). In both sexes, proboscis monkey has reddishbrown fur but a male has more striking and contrasts in colour, with a mane hair behind its back (Bennett \& Gombek, 1993). The weight of an adult male proboscis monkey can reach up to $24 \mathrm{~kg}$, while an adult female is usually half of this size, making the proboscis monkey to be the largest Colobine monkey (Allen \& Coolidge, 1940; Schultz, 1942; Wolfheim, 1983; Phillipps \& Phillipps, 2016). An infant proboscis monkey is born with dark brown fur and its face is covered with dark blue colour (Bennett \& Sebastian, 1988).

The natural habitats of proboscis monkey are restricted to the lowland coastal rainforests and always associated with waterways including mangroves, riverine, peat and fresh water swamp forests (Kawabe \& Mano, 1972; Salter et al., 1985; Bennett \& Gombek, 1993; Meijaard \& Nijman, 2000). During the day, it will forage inland, normally less than $1 \mathrm{~km}$ away from the riverbank and always return before dusk to sleep (Salter et al., 1985; Bennett \& Sebastian, 1988; Yeager, 1989; Matsuda et al., 2008). The basic social unit of proboscis monkey is a harem group that consists of an adult male, several females and their offsprings (Bennett \& Sebastian, 1988). Within several groups, a secondary level of social organisation may occur where they may travel and sleep together in close proximity (Bennett \& Sebastian, 1988).

In the Red List of Threatened Species, International Union for the Conservation of Nature (IUCN), proboscis monkey is classified as an Endangered species (IUCN, 2017) and is listed in Appendix $\mathrm{I}$, in the Convention on International Trade in Endangered Species of Wild Fauna and Flora (CITES). Similar to other primates, habitat degradation and destruction become the major threats to the survival of proboscis monkey in Borneo (Meijaard \& Nijman, 2000). The population trends of proboscis monkey showed a great decreased by more than $50 \%$ during the past 40 years (Meijaard et al., 2008). In Sarawak, many of the 
natural habitats of proboscis monkey are exposed to logging, agriculture and tourism activities (Salter \& MacKenzie, 1985). The degradation of mangroves and peat swamp forests generally leads to a reduction of the proboscis monkey population (Bennett, 1988).

Mangrove forest is one of the preferred habitats for proboscis monkey (Phillipps \& Phillipps, 2016). Mangrove forest not only provides refuge for proboscis monkey but it is also economically beneficial. In KWNP alone, mangrove forest supported fisheries worth for more than US\$21.1 million. In addition, mangrove forest in KWNP yielded annually US $\$ 123,217$ in timber production, US $\$ 3.7$ million from the tourism industry and provided for more than 3,000 jobs for the locals (Bennett \& Reynolds, 1993). KWNP is the only area in Sarawak that remains as an important refuge for mangrove flora and fauna, including proboscis monkey (Bennett \& Reynolds, 1993).

Other than KWNP, there are several localities in Sarawak where the proboscis monkeys can be found including Bako National Park, Samunsam Wildlife Sanctuary, Maludam National Park, Limbang Mangrove National Park and Kuala Lawas Forest Reserve. However, to date, there are still lack of efforts to update the population status of this endangered species. The status of the proboscis monkey population in Sarawak is still depending on the outdated data done in the 80s (Salter \& MacKenzie, 1985; Bennett et al., 1987). Thus, this study was conducted to estimate the current population status of proboscis monkey in mangrove forest at KWNP, and to update the current estimation of proboscis monkeys left in Sarawak. It is important to have a reliable and updated data on the population size because this is the basic information needed when constructing a conservation plan.

\section{MATERIALS AND METHODS}

\section{Study Area}

The survey was conducted at KWNP, located approximately $15 \mathrm{~km}$ from Kuching City, Sarawak. Previously, this park was known as Sarawak Mangrove Forest Reserve before it was gazetted as a national park in 2000, with an area of 6,610 ha. On $8^{\text {th }}$ November 2005, KWNP was designated as the first Ramsar Site in Sarawak under the Ramsar Convention (Beavitt \& Tuen, 2010). Surveys were concentrated in the mangrove forest at KWNP as mangroves cover almost $70 \%$ of the total area of the park (Table $1)$.

\section{Survey Technique}

Boat survey on proboscis monkey in KWNP was conducted following Bennett (1986). This survey was conducted by direct observation along the mangrove riverbank in the early morning and late evening. In the morning sessions, the surveys were started at dawn and finished about 90 minutes later. While in the evening sessions, the surveys were started about 60-90 minutes before dusk. Surveys were conducted only in these limited periods of time as to adapt to the natural behaviour of the proboscis monkeys that sleep at the riverbank (Payne \& Francis, 2007). In order to cover the large mangrove area in KWNP, the surveys were designated into two parts. During the first part of the survey, which was conducted on $30^{\text {th }}$ September until $2^{\text {nd }}$ October 2015, the survey covered the western part of the park, mainly in Sungai Sibu Laut. The second part of the survey was conducted on $11^{\text {th }}$ January until $13^{\text {th }}$ January 2016. At this time, surveys covered the eastern part of the park, specifically along Batang Salak (Figure 1). In each part of the survey, three days were allocated allowing at least six trips of surveys in each part. The oneway survey was conducted to prevent double

Table 1. Total land use areas based on geospatial analysis at Kuching Wetland National Park.

\begin{tabular}{lcc}
\hline Vegetation Type & Total Area $\left(\mathrm{km}^{2}\right)$ & Proportion $(\%)$ \\
\hline Bare Land & 0.60 & 0.82 \\
Cultivated Land/ Secondary Vegetation & 1.61 & 2.20 \\
Infrastructure/ HQ & 0.37 & 0.50 \\
Tropical Heath & 7.47 & 10.23 \\
Mangrove & 49.97 & 68.40 \\
Peat Swamp & 3.04 & 4.17 \\
Water body & 10.00 & 13.68 \\
\hline Total & 73.06 & 100.00 \\
\hline
\end{tabular}




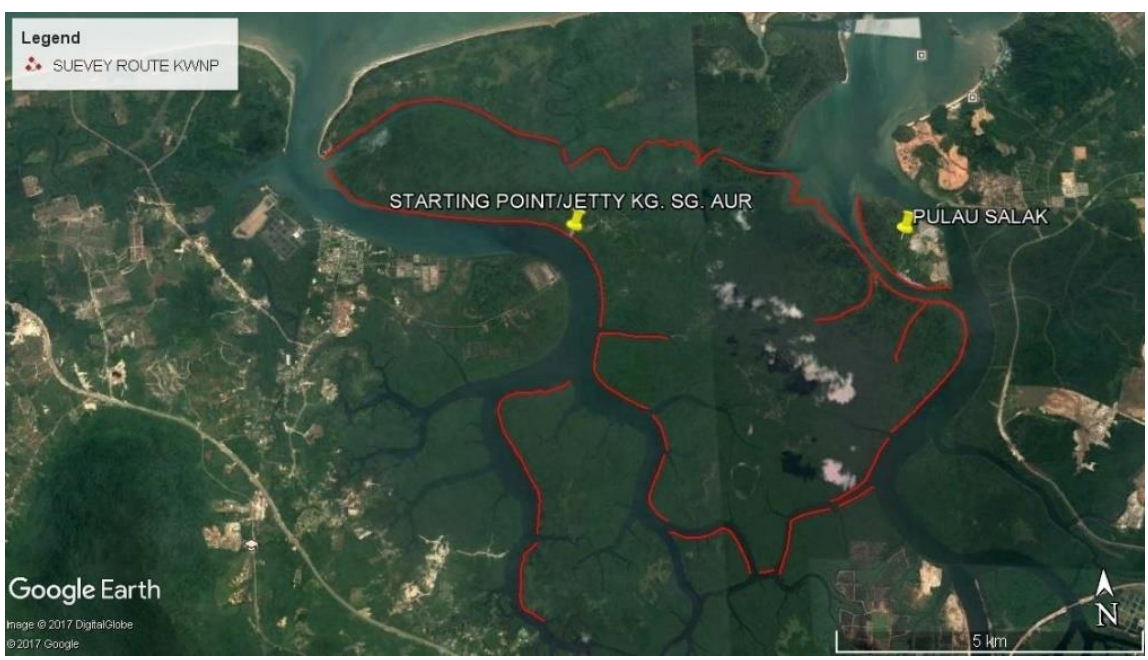

Figure 1. Survey route in KWNP (Source: Google Earth Pro 7.1.8.3036).

counting of individual of proboscis monkey. At least two enumerators were involved during the survey.

\section{Data Collection}

Once any proboscis monkey individuals were sighted, the boat engine was immediately switched off, to avoid further disturbance and causing the proboscis monkey to move away from the location. The size of the group was recorded and identified into sex and age classes based on Bennett and Sebastian (1988). The coordinates of each group sighted were recorded by using Geographic Positioning System (Garmin 64s). Any individuals of proboscis monkey within $50 \mathrm{~m}$ radius were considered as the same group.

\section{Mapping and Area Measurement Analysis}

The soil map of Sarawak dated in 1968 (source from Department of Agriculture, Soil Survey Division) was updated and rectified to estimate the current mangrove area in KWNP (Figure 2). This process was done by using Geographic Information System software programme (QGIS version 2.14.10) with the aids of current forest cover, obtained from the satellite image of Landsat 8, Sentinel 2 MODIS 2016 and SRTM 1 -arcsecond. Soil map was used in the rectification process since soil type is strongly correlated with forest type distribution (Hazebroek \& Abang Kashim, 2006). Additional, land use maps were acquired from the Department of Survey and Mapping Sarawak, including map of the global distribution of mangroves created by UNEPWCMC-Global in 2011 and Sarawak topography map series DNMM5201.

\section{Data Analysis}

The population density of proboscis monkeys in KWNP was estimated by dividing the cumulative number of individuals sighted with the total surveyed area. The total surveyed area was the cumulative distance of the surveyed riverbank multiplied with $0.75 \mathrm{~km}$ perpendicular distance from the riverbank. The analysis of the estimated population size was correlated with the population density obtained. The estimated population density of proboscis monkey was multiplied by the total area of mangrove forest in KWNP to obtain the estimated population size of proboscis monkey in the mangrove forest at KWNP. The formulas used were as below:

\section{Population density $=$ \\ Cumulative number of individuals sighted Total surveyed area $(\mathrm{sq} \mathrm{km})$ \\ Total surveyed area $=$ Cumulative distance of
surveyed riverbank $(\mathrm{km}) \times 0.75 \mathrm{~km}$ \\ Population size $=$ Population density $\mathrm{x}$ total area of mangrove forest in $K W N P$}

Home range size plays an important role in the estimation of population density of proboscis monkey (Bernard \& Hamzah, 2006). In order to obtain the home range size of proboscis monkey in KWNP, a periodic observation is needed which could not be conducted in this study. Thus, perpendicular distance of $0.75 \mathrm{~km}$ from the riverbank was applied in this study to estimate the total surveyed area by multiplying the cumulative distance of surveyed riverbank with $0.75 \mathrm{~km}$. This figure was adopted from the study 


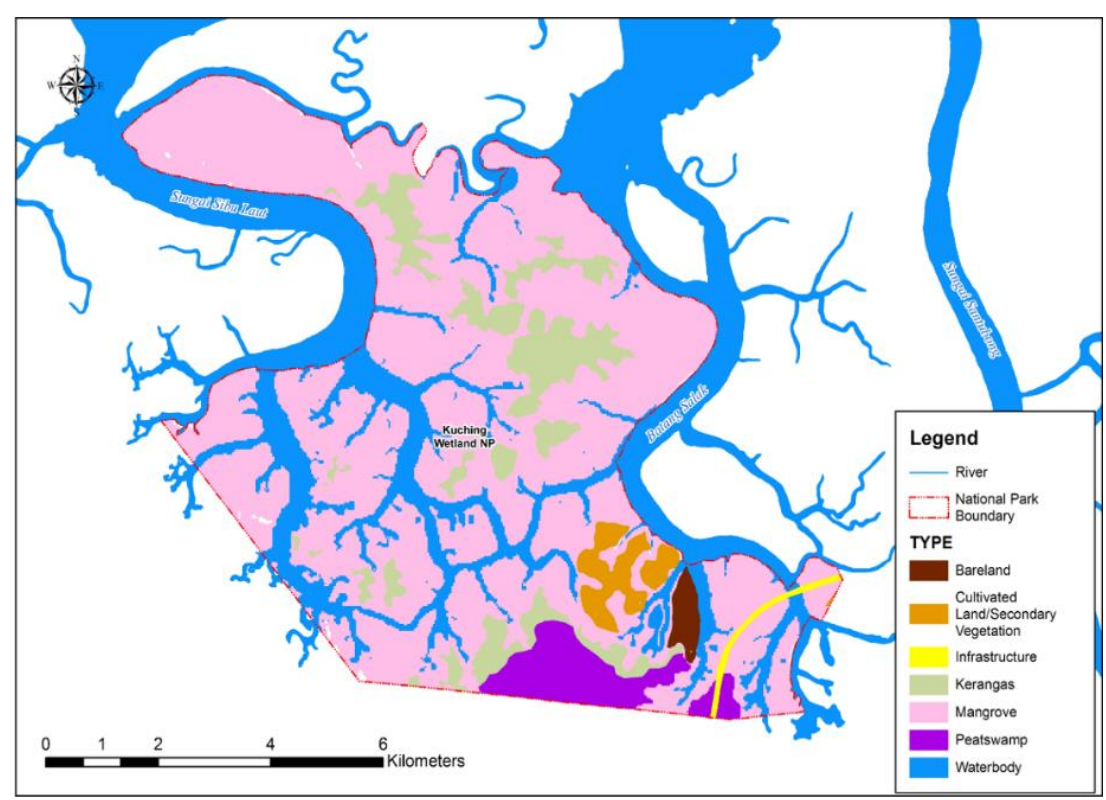

Figure 2. Vegetation map of KWNP (Source: Department of Agriculture, Soil Survey Division).

on the ranging behaviour of proboscis monkey in Samunsam Wildlife Sanctuary and Bako National Park. The distance of $0.75 \mathrm{~km}$ is the maximum perpendicular distance from the riverbank where the proboscis monkey might travel from its sleeping sites (Salter et al., 1985). This distance is applied in this study, since this is the closest and available ranging distance that was recorded in Sarawak. Besides, it is still in the range of the daily movement of proboscis monkey that have been reported (Bennett \& Sebastian, 1988; Boonratana, 2000; Sebastian, 2000; Bismark, 2010).

\section{RESULTS}

A cumulative distance of $128.91 \mathrm{~km}$ of mangrove riverbank was surveyed over the sixday survey in this park. A cumulative of 158 individuals from 15 harem groups, one all-male group and three solitary males of proboscis monkeys were sighted throughout the survey. Based on the analysis, the population size of the proboscis monkey in KWNP was estimated at 82 individuals with the estimated population density of 1.63 individuals $/ \mathrm{km}^{2}$ or 0.20 groups $/ \mathrm{km}^{2}$ (Table 2).

\section{DISCUSSION}

No studies on estimation of proboscis monkey based on vegetation have been conducted previously. The analysis of this study was designed to estimate the population density and population size based on the vegetation types where the proboscis monkeys were encountered. The estimated population density of proboscis monkey was extrapolated only to the mangrove area to estimate the population size. Thus, the extrapolation of the population density was focused on mangrove forest rather than extrapolating the population density to the whole area of KWNP, which could result in over estimation. In addition, the estimated population density itself has represented the population of proboscis monkey in mangroves but not for the whole area of the KWNP.

The usage of a cumulative number of individuals in the analysis of population density was found to be more precise than other previous studies, which used the maximum number of individuals in their analysis (Bernard \& Hamzah, 2006; Ali et al., 2009). The cumulative number applied in the analysis of the population density of this study was actually representing the

Table 2. The estimated population of proboscis monkey in mangroves at KWNP.

\begin{tabular}{|c|c|c|c|c|c|c|c|}
\hline \multirow{2}{*}{$\begin{array}{c}\text { Cumulative } \\
\text { number of } \\
\text { individuals } \\
\text { sighted }\end{array}$} & \multirow{2}{*}{$\begin{array}{c}\text { Cumulative } \\
\text { number of } \\
\text { groups sighted }\end{array}$} & \multirow{2}{*}{$\begin{array}{l}\text { Cumulative } \\
\text { distance of } \\
\text { surveyed } \\
\text { riverbank }(\mathrm{km})\end{array}$} & \multirow{2}{*}{$\begin{array}{c}\text { Total } \\
\text { surveyed } \\
\text { area }\left(\mathrm{km}^{2}\right)\end{array}$} & \multirow[t]{2}{*}{$\begin{array}{l}\text { Total forest } \\
\text { area }\left(\mathrm{km}^{2}\right)\end{array}$} & \multicolumn{2}{|c|}{ Estimated population density } & \multirow[t]{2}{*}{$\begin{array}{c}\text { Estimated } \\
\text { population size }\end{array}$} \\
\hline & & & & & Individuals $/ \mathrm{km}^{2}$ & Groups $/ \mathrm{km}^{2}$ & \\
\hline 158 & 19 & 128.91 & 97.68 & 49.97 & 1.63 & 0.20 & 82 \\
\hline
\end{tabular}


average individuals, as it was divided by the cumulative surveyed area. In order to cover as much area of a survey within the limited period of the survey in every session, the use of maximum number could be less applicable. However, the usage of maximum number might be applicable only if the distance of the survey were fixed. Moreover, it has to be implemented within the limited period of survey for every session and the survey covered the same river for every trip.

The number of proboscis monkey in KWNP was found to be unusually different between both parts of the surveys. The number of sighted groups during the first part of the survey was almost six times lower than the second part. The population was found to be more around Batang Salak with 16 groups recorded while only three groups were recorded along Sungai Sibu Laut. This situation of less proboscis monkey along Sungai Sibu Laut was probably due to the heavy usage of the river by the local communities as it is near to Telaga Air town, the main town for the surrounding local people. Some groups of the proboscis monkey were sighted outside of the national park boundary, the other side of the river. These groups were also taken into account since proboscis monkey is known for its ability to swim across the river (Bennett \& Sebastian, 1988). Proboscis monkey has been reported to swim underwater for up to $20 \mathrm{~m}$ to avoid predation (Bennett \& Gombek, 1993).

Based on the observation during the survey, there were disturbances toward the proboscis monkey population in KWNP that may be worth to be mentioned. Firstly, the use of the area by locals for their economic activities, which are wood pole collection and fishing activities. These activities were not seemed to affect the proboscis monkey adversely but it limited the habitat used by the proboscis monkeys as they were avoiding those areas with human-induced disturbances (Salter et al., 1985). Removal of poles, especially from Rhizophora sp., does not break the canopy of the mangrove. Pole collection was selective and like the fishing activities, it was conducted on a small scale by the local community. However, cautious also need to be taken given this park is easily accessible by the public for fishing activities. Poachers from outside of the area may pretend that they come for fishing, but actually they may hunt for proboscis monkeys. The natural behaviour of this species that spends most of its time at the riverbank, makes these animals more vulnerable to be hunted (Bennett, 1987). Routine patrolling is needed in this park to avoid illegal hunting activities.

An ongoing mining activity in Pulau Salak is a more severe disturbance to the population of proboscis monkey in KWNP. Even though Pulau Salak is not within the boundary of the park, a big number of proboscis monkeys were recorded from this area. A huge area of Pulau Salak was cleared for mining a limestone quarry which directly affects the habitat of proboscis monkey. Within Pulau Salak, there is a small Malay village known as Kampung Salak. Hunting activities by local communities, especially from Kampung Salak and nearby villages, were not in existence based on the informal interview and personal observations did during the survey. This is probably because the majority of the nearby villagers are Muslims and it is taboo for them to consume this animal.

\section{CONCLUSION}

The population size of proboscis monkey in the mangrove vegetation at KWNP was estimated at 82 individuals with the estimated population density of 1.63 individuals $/ \mathrm{km}^{2}$ or 0.20 groups $/ \mathrm{km}^{2}$. Survey on proboscis monkey population in Sarawak should be a continuous endeavour. Updated and reliable data on the population estimation of proboscis monkey is urgently needed in the efforts to construct a relevant conservation plan to ensure the survival of this animal. This is also true for other important proboscis monkey sites, to obtain an estimation of population size and population density for the whole area of Sarawak.

\section{ACKNOWLEDGEMENTS}

This project was fully funded by Fundamental Research Grant Scheme (FRGS /SG03(02)/1141/2014(08)). The authors would like to thank Faculty of Resource Science and Technology, Universiti Malaysia Sarawak (UNIMAS) for providing the facilities and transportation needed in conducting this study. The authors wish to thank Mr. Borhan and Mdm. Misut for their assistance and hospitality during the field work conducted in KWNP. The authors would also like to express their gratitude to Sarawak Forestry Department and Sarawak Forestry Corporation for permission in allowing them to conduct this study (Permit No. NCCD.907.4.4(JLD.13)-287 and Park Permit No. WL027/2016). 


\section{REFERENCES}

Ali, M.R., Bernard, H. \& Hanya, G. (2009). The population size and distribution of proboscis monkeys (Nasalis larvatus) based on a brief study in Garama, Klias Peninsula, Sabah, Malaysia. Journal of Tropical Biology and Conservation, 5: 67-70.

Allen, G.M. \& Coolidge, H.J. (1940). Asiatic primate expedition collections: mammals. Bulletin of the Museum of Comparative Zoology, 87: 131-166.

Beavitt, W. \& Tuen, A.A. (2010). Kuching Wetlands National Park (SWAMP): a photographic guide to the plants and animals of Malaysia's coastal and mangrove habitats. Kota Samarahan: Universiti Malaysia Sarawak Publication. P 3.

Bennett, E.L. \& Gombek, F. (1993). Proboscis monkeys of Borneo. Natural History Publications (Borneo) Sdn. Bhd. \& Koktas Sabah, Ranau, Sabah, Malaysia. Pp 84-99.

Bennett, E.L. \& Reynolds, C.J. (1993). The value of a mangrove area in Sarawak. Biodiversity and Conservation, 2(4): 359-375.

Bennett, E.L. \& Sebastian, A.C. (1988). Social organization and ecology of proboscis monkeys (Nasalis larvatus) in mixed coastal forest in Sarawak. International Journal of Primatology, 9(3): 233-255.

Bennett, E.L., Caldecott, J.O., Kavanagh, M. \& Sebastian, A.C. (1987). Current status of primates in Sarawak. Primate Conservation: The Newsletter and Journal of the IUCN/SSC Primate Specialist Group, 8: 184-186.

Bennett, E.L. (1986). Proboscis monkeys in Sarawak: their ecology, status, conservation and management. World Wildlife Fund Malaysia, Kuala Lumpur and New York Zoological Society, New York. Pp 94-99.

Bennett, E.L. (1987). The value of mangroves in Sarawak. Sarawak Gazette, 63: 12-21.

Bennett, E.L. (1988). Proboscis monkeys and their swamp forests in Sarawak. Oryx, 22(2): 69-74.

Bernard, H. \& Hamzah, Z. (2006). Population size and distribution of the proboscis monkey (Nasalis larvatus) in the Klias Peninsula, Sabah, Malaysia. Malayan Nature Journal, 56(2): 153-163.

Bismark M. (2010) Proboscis monkey (Nasalis larvatus): bio-ecology and conservation. In Gursky-Doyen, S. \& Supriatna, J. (Eds.), Indonesian primates: developments in primatology: progress and prospects. New York: Springer. Pp. 217-233.

Boonratana, R. (2000). Ranging behavior of proboscis monkeys (Nasalis larvatus) in the Lower Kinabatangan, northern Borneo. International Journal of Primatology, 21(3): 497518.
Hazebroek, H.P. \& Abang Kashim, A.M. (2006). National Parks of Sarawak. Kota Kinabalu: Natural History Publications (Borneo). Pp 313345.

IUCN. (2017). International Union for Conservation of Nature (IUCN) Red List of Threatened Species Version 2017.2. https://www.iucnredlist.org./ Downloaded on 26 May 2017.

Kawabe, M. \& Mano, T. (1972). Ecology and behaviour of the wild proboscis monkey, Nasalis larvatus (Wurmb), in Sabah, Malaysia. Primates, 13(2): 213-227.

Matsuda, I., Tuuga, A., Akiyama, Y. \& Higashi, S. (2008). Selection of river crossing location and sleeping site by proboscis monkeys (Nasalis larvatus) in Sabah, Malaysia. American Journal of Primatology, 70(11): 1097-1101.

Meijaard, E. \& Nijman, V. (2000). Distribution and conservation of the proboscis monkey (Nasalis larvatus) in Kalimantan, Indonesia. Biological Conservation, 92(1): 15-24.

Meijaard, E., Nijman, V. \& Supriatna, J. (2008). Nasalis larvatus The IUCN Red List of Threatened $\quad 2008$. https://www.iucnredlist.org/details/14352/0. Downloaded on 25 January 2018.

Payne, J. \& Francis, C.M. (2007). A field guide to the mammals of Borneo. Kota Kinabalu: The Sabah Society. Pp 228.

Phillipps, Q. \& Phillipps, K. (2016). Phillipps' field guide to the mammals of Borneo and their ecology: Sabah, Sarawak, Brunei, and Kalimantan. USA: Princeton University Press. Pp. 174-179.

Salter, R.E. \& MacKenzie, N.A. (1985). Conservation status of proboscis monkey in Sarawak. Biological Conservation, 33(2): 119-132.

Salter, R.E., MacKenzie, N.A., Nightingale, N., Aken, K.M. \& Chai, P.K.P. (1985). Habitat use, ranging behaviour and food habits of the proboscis monkey, Nasalis larvatus (van Wurmb), in Sarawak. Primates, 26(4): 436-451.

Schultz, A.H. (1942). Growth and development of the proboscis monkey. Bulletin of the Museum of Comparative Zoology at Harvard College, 89(6): 279-314.

Sebastian, A.C. (2000). Proboscis monkey in Danau Sentarum National Park. Borneo Research Bulletin, 31: 359-371.

Wolfheim, J.H. (1983). Primates of the world: distribution, abundance and conservation. Seattle: University of Washington Press. Pp 553.

Yeager, C.P. (1989). Feeding ecology of the proboscis monkey (Nasalis larvatus). International Journal of Primatology, 10(6): 497-530. 